ARTICLE

\title{
Re-evaluating the hiddenness argument from above
}

\author{
Kevin Vandergriff ${ }^{1,2}$
}

Received: 5 March 2018 / Accepted: 27 June 2018 / Published online: 4 July 2018

(c) The Author(s) 2018

\begin{abstract}
J. L. Schellenberg's hiddenness argument for atheism (2015) assumes that God's perpetual openness to a relationship with any finite person is consistent with their perpetual flourishing. However, I argue that if Aquinas-Stump's account of the nature of love is true, then any finite person flourishes the most only if they attain the greatest degree of union among God and all relevant parties. Moreover, if Humean externalism is true, then any finite person might not have their greatest attainable degree of union among God and all relevant parties, as soon as possible, unless God sacrifices some time in the union-not the whole union-with them. Accordingly, God's perpetual openness might not be consistent with the future flourishing of any finite person-from which it follows that a crucial assumption of the hiddenness argument might not be true.
\end{abstract}

Keywords Schellenberg $\cdot$ Hiddenness $\cdot$ Nonresistant nonbelief $\cdot$ Atheism $\cdot$ AquinasStump $\cdot$ Love $\cdot$ Motivational externalism

Rick Deckard (Blade Runner 2049): Sometimes to love someone, you got to be a stranger.

\section{Introduction}

Since the publication of J. L. Schellenberg's book, Divine Hiddenness and Human Reason (1993), "divine hiddenness" has come to refer to the phenomenon of nonresistant nonbelief (Schellenberg 2007, 204 and 226). Any finite person is a nonresistant nonbeliever if and only if they fulfill three conditions. First, they must possess the cognitive and affective faculties needed to participate in a personal relationship with God. Second, they must lack the belief that God exists. Third, the absence of theistic belief must not be the result of their own psychological or

Kevin Vandergriff

kevinvandergriff@yahoo.com

1 University of Birmingham, Birmingham, UK

2 California State University, Sacramento, Sacramento, CA, USA 
behavioral opposition towards God, or personal relationship with God, or any of the apparent implications of such a relationship (Schellenberg 2008).

J. L. Schellenberg has pioneered a divine hiddenness argument to believe that nonresistant nonbelief would not exist if there were a God (Schellenberg 2017, 1):

(S1) If a perfectly loving God exists, then there exists a God who is always open to a personal relationship with any finite person.

(S2) If there exists a God who is always open to a personal relationship with any finite person, then no finite person is ever nonresistantly in a state of nonbelief in relation to the proposition that God exists.

(S3) If a perfectly loving God exists, then no finite person is ever nonresistantly in a state of nonbelief in relation to the proposition that God exists. [HS (S1), (S2)]

(S4) Some finite persons are or have been nonresistantly in a state of nonbelief in relation to the proposition that God exists.

(S5) No perfectly loving God exists. [MT (S3), (S4)]

(S6) If no perfectly loving God exists, then God does not exist.

(S7) God does not exist. [MP (S5), (S6)]

Premise (S1) maintains that a perfectly loving God (if such a God exists) is perpetually open to a personal relationship with any finite person $\mathrm{P}$, in a perfectly loving manner, such that there is nothing God does that prevents $\mathrm{P}$ from being able to participate in a personal relationship with God (Schellenberg 2016, 21). Schellenberg gives three reasons that support the truth of premise (S1). First, it is self-evident that a perfectly loving God, like the best human lover, would ensure that a personal relationship was always possible for those she loved. Moreover, our flourishing, which a perfectly loving God would always desire, would be immeasurably enhanced by a personal relationship with God (Schellenberg 1993, 17-18). Finally, a perfectly loving God would value a personal relationship with any finite person for its own sake (Schellenberg 2016, 19).

Put simply; the idea of premise (S2) is that it is necessary to believe that God exists before someone can believe in God:

... $[\mathrm{H}]$ ow can I experience nature as the creature of God or hear God speak to me (interpreting it as God speaking) or consciously experience Divine forgiveness and support or feel grateful to God or experience God's loving and inspiring presence and respond thereto in love and obedience and worship if I do not believe that there is a God (Schellenberg 2007, 204)?

Accordingly, given S1, any nonresistant finite person will always believe that God exists whenever they can participate in a personal relationship with God.

Premises (S1) and (S2) jointly entail sub-conclusion (S3), i.e., if a perfectly loving God exists, then no instances of nonresistant nonbelief would exist in this (or any possible) world.

Premise (S4) is an empirical premise that generalizes from four widelyaccepted examples of capable nonbelief to the conclusion that there is or has been 
at least one nonresistant nonbeliever. ${ }^{1}$ After all, the probability is vanishingly small that all these hundreds of millions of capable nonbelievers are or have been resistant to relating personally to God.

Premises (S3) and (S4) jointly entail sub-conclusion (S5), i.e., no perfectly loving God exists.

Premise (S6) operates on the traditional Judeo-Christian-Islamic concept of God, which minimally includes the thesis that God is morally perfect; and in that connection, must be perfectly loving. Accordingly, if God exists, then that entails a perfectly loving God exists. Therefore, if no perfectly loving God exists, then God does not exist.

Premises (S5) and (S6) jointly entail main conclusion (S7), i.e., God does not exist.

Since sub-conclusions (S3) and (S5), and main conclusion (S7), follow deductively from the premises before them, the only question is: Are premises (S1), (S2), (S4), and (S6) true? In my judgment, Schellenberg has convincingly argued that premises (S2), (S4), and (S6) are true (Schellenberg 2015). Therefore, my critical appraisal of Schellenberg's hiddenness argument will focus on premise (S1).

Premise (S1) assumes that God's perpetual openness to a relationship with any finite person would not hinder the perpetual flourishing of all relevant parties, or any relationship that may exist or come to exist between them:

An important principle I have recently argued we should accept-call it the Openness Principle - has it that a loving person maintains openness to a relationship with the one she loves whenever she has the resources to accommodate the consequences of such openness... as premise 1 of the hiddenness argument has it... (Schellenberg 2017, 2). [So]... a lover may lack the resources to accommodate the possible consequences of openness, that is, to make them consistent with the flourishing of all relevant parties and of any relationship that may exist or come to exist between them. But since God is not such a lover, we may ignore this qualification hereafter (Schellenberg 2016, 20).

However, this background assumption of premise (S1) might not be true. Why? Because if Aquinas-Stump's account of the nature of love is true, then any finite person flourishes the most only if they attain the greatest degree of union among God and all relevant parties (i.e., self and others). Moreover, if Humean externalism is true, then any finite person might not have their greatest attainable degree of union among God and all relevant parties, as soon as possible (a.s.a.p.), unless God sacrifices some time in the union —not the whole union—with them.

Therefore, God's perpetual openness to union with any finite person might hinder the flourishing of their future union among God and all relevant parties; and accordingly, hinder their future flourishing. Given that a perfectly loving God might not have the resources to accommodate this possible consequence of perpetual

\footnotetext{
1 Schellenberg (2007, 228-242): (1) Former believers: Those who have lost the theistic faith they once had and earnestly wish to regain it. (2) Lifelong seekers: Honest seekers of truth who remain agnostics and atheists, including those whose search leads them to convert to non-theistic religions. (3) Converts to non-theistic religions: Theists who become adherents of non-theistic religions, or nonresisters who become adherents of non-theistic religions (sometimes because of non-theistic religious experiences). (4) Isolated non-theists: Hunter-gatherers prior to the advent of theistic concepts and beliefs, and members of cultures that lack the idea of a personal and perfectly loving God.
} 
openness, it follows that such a God might not be perpetually open to union with any (i.e., every) finite person. In that connection, premise (S1) might not be true.

For the sake of clarity, here is the standard form of the main argument I defend to believe that premise (S1) might not be true:

(A1) If a perfectly loving God exists, then such a God always intrinsically desires any finite person to have their greatest attainable flourishing a.s.a.p.

(A2) If a perfectly loving God exists who always intrinsically desires any finite person to have their greatest attainable flourishing a.s.a.p., then such a God always intrinsically desires any finite person to have their greatest attainable degree of union among God and all relevant parties a.s.a.p.

Therefore,

(A3) If a perfectly loving God exists, then such a God always intrinsically desires any finite person to have their greatest attainable degree of union among God and all relevant parties a.s.a.p. [HS (A1), (A2)]

(A4) If a perfectly loving God exists who always intrinsically desires any finite person to have their greatest attainable degree of union among God and all relevant parties a.s.a.p., then such a God always intrinsically desires any finite person to attain the state of wholeheartedly desiring to comply with what morality requires a.s.a.p.

Therefore,

(A5) If a perfectly loving God exists, then such a God always intrinsically desires any finite person to attain the state of wholeheartedly desiring to comply with what morality requires a.s.a.p. [HS (A3), (A4)]

(A6) If a perfectly loving God exists who always intrinsically desires any finite person to attain the state of wholeheartedly desiring to comply with what morality requires a.s.a.p., then such a God always intrinsically desires to optimally sustain any nonresistant finite person's global second-order desire to be moral.

Therefore,

(A7) If a perfectly loving God exists, then such a God always intrinsically desires to optimally sustain any nonresistant finite person's global secondorder desire to be moral. [HS (A5), (A6)]

(A8) If a perfectly loving God exists who always intrinsically desires to optimally sustain any nonresistant finite person's global second-order desire to be moral, then such a God might derivatively desire to permit various types and tokens of nonresistant nonbelief for some time.

Therefore,

(A9) If a perfectly loving God exists, then such a God might derivatively desire to permit various types and tokens of nonresistant nonbelief for some time. [HS (A7), (A8)]

(A10) If a perfectly loving God exists who might derivatively desire to permit various types and tokens of nonresistant nonbelief for some time, then such a God might not be perpetually open to union with any finite person. 
Therefore,

(A11) If a perfectly loving God exists, then such a God might not be perpetually open to union with any finite person. [HS (A9), (A10)]

Notice that sub-conclusions (A3), (A5), (A7), and (A9), and main conclusion (A11), follow deductively from the premises before them. Also, notice that if main conclusion (A11) is true, then premise (S1) of Schellenberg's hiddenness argument might have a true antecedent and a false consequent. In that connection, premise (S1) might not be true. As such, Schellenberg's hiddenness argument might not show that atheism is true.

In the next section, I argue for the truth of premises (A1), (A2), (A4), and (A6) using Aquinas-Stump's account of the nature of love. Then, I argue for the truth of premises (A8) and (A10) using Humean externalism. After that, the following two sections see a consideration of two objections to my main argument followed by a conclusion.

However, it is vital that I make three clarifications regarding my main argument above to avoid gratuitous confusion. First, I aim to undercut, rather than rebut, premise (S1) of Schellenberg's hiddenness argument. Second, to the best of my knowledge, nobody has used Aquinas-Stump's general account of love and Humean externalism, in the way I do, to develop an undercutting defeater of premise (S1). Third, I support premises (A1), (A2), (A4), (A6), (A8), and (A10) by reasoning "from above" (with abstract reflection on the nature of love and moral motivation). That is, if Aquinas-Stump's account of love is true, then it is necessarily true (de dicto) because it encapsulates the nature of love. Moreover, if Humean externalism is true, then it is necessarily true (de dicto)_-whether we have libertarian free will or not-because it encapsulates the nature of moral motivation. Therefore, I do not commit the familiarity fallacy that Schellenberg has repeatedly cautioned against, where someone takes assorted contingent facts about our world as unobjectionable givens when doing natural theology (Schellenberg 2007, 260-261).

\section{Aquinas-Stump's account of the nature of love}

\section{Premise (A1)}

Aquinas-Stump's account of the nature of love requires two interconnected desires: (D1) the desire for the good of the beloved, and (D2) the desire for union with the beloved. The ultimate proper object and cause of these two desires is the good alone. $^{2}$ Accordingly, the relevant implicit condition on each of the desires of love is 'for the sake of goodness' rather than the 'for its own sake' Schellenberg appeals to in defense of premise (S1):

That is, if we ask the lover, "why do you want the good of the beloved?, or 'why do you want union with the beloved?', on Aquinas's view the answer should not be 'I just do; it's a final end for me.' Rather, the answer should be, 'because it's good'-because it is good that the beloved should have what

\footnotetext{
${ }^{2}$ This includes moral, non-moral, and metaphysical goodness (Stump 2010, 93).
} 
is good for him; because it is good that the lover should be united with the beloved... (Stump 2010, 93).

However, with regard to the first desire of love, I hasten to add that intrinsically desiring the good of the beloved may sometimes require the lover to derivatively desire the conditions that are necessary to promote the beloved's future flourishing (Stump 2010, 93-94).

For example, suppose a pediatrician tells two loving parents that they must sleep train their six-month-old infant to promote his or her future flourishing. Further suppose that the pediatrician recommends to the parents that they use the Ferber method as the best way to sleep train their infant. ${ }^{3}$ Given their pediatrician's recommendation, and the well-established future benefits of the Ferber method, these loving parents elect to sleep train their infant using this method.

Given this background information, it can be argued that these loving parents intrinsically desire the true flourishing of their infant. At the same time, however, these loving parents only derivatively desire the conditions that are necessary for their infant to acquire the future benefits of such training - namely, they must remain hidden for a predetermined amount of time while their infant cries. Of course, one assumes that the appropriate use of the Ferber method is not an evil and will not cause short-term or long-term harm to an infant. Granting that assumption illustrates the further point that these parents can justifiably sleep train their infant, using the Ferber method, without needing the explicit or implicit consent of their child to do so (Stump 2010, Ch. 13).

Relatedly, if a perfectly loving God exists, then such a God always intrinsically desires the true good of any finite person. However, as I shall argue, that may sometimes require such a God to derivatively desire to permit nonresistant nonbelief for some time in order to promote the future flourishing of all relevant parties. I hasten to add that since the logic of the divine hiddenness argument under consideration does not involve any relationship between nonresistant nonbelief and facts about evil (Schellenberg 2007, 226) or pain and suffering (Schellenberg 2010, 8), considerations of consent do not charitably arise as potential objections to my main argument. In what follows, I understand the desire for the good of the beloved as qualified by these remarks.

At present, here is the crucial point: if a perfectly loving God exists, then such a God always intrinsically desires any finite person to have their greatest attainable flourishing a.s.a.p. Consider two reasons in support of this conditional claim. First, it is self-evident. That is, just like the best human lover, a perfectly loving God (if those words mean anything) would never intrinsically desire any unnecessary delays in the beloved having their greatest attainable flourishing. Second, a perfectly loving God would always intrinsically desire any finite person to have their greatest attainable flourishing a.s.a.p. because it is good-rather than for its own sake.

In the next sub-section, I explain one necessary condition of any finite person having their greatest attainable flourishing a.s.a.p.

\footnotetext{
3 The Ferber method involves teaching infants to self-soothe by allowing them to cry for a predetermined amount of time before receiving external comfort from caregivers.
} 


\section{Premise (A2)}

For Aquinas, and many other theists, there is some sort of strong connection between the existence of God and the existence of goodness - such that, at a minimum, God is the paradigm of goodness. Consequently, the proper object and cause of the two desires of love includes God and any finite person that exemplifies (God's) goodness to some degree. As such, love is primarily the love of persons.

Relatedly, Aquinas thought it was perspicuous that the greatest flourishing for any person only attains in a union of love. A union of love is a special personal relationship that requires the lover and the beloved to share significant personal presence, and thus, significant closeness (Stump 2010, Ch. 6). Accordingly, union with God is the greatest possible flourishing any person can have because it would be the greatest possible union of love.

Moreover, according to Aquinas, the greatest possible flourishing for any person is the most shareable form of flourishing because it is "not diminished by being distributed" (Stump 2010, 387). Accordingly, “...human loves can themselves be woven into the shareable love between God and a human person (Stump 2010, 387)." Consequently, the greatest possible flourishing for any finite person is "more precisely described as the shared union of love among [all relevant parties] and God (Stump 2010, 387)." However, even this claim needs qualification because “...it is possible to have more or less [emphasis added] of a loving relationship in union with God [and all relevant parties] (Stump 2010, 390)."

Therefore, if a perfectly loving God exists who always intrinsically desires any finite person to have their greatest attainable flourishing a.s.a.p., then such a God always intrinsically desires any finite person to have their greatest attainable degree of union among God and all relevant parties a.s.a.p.

Premises (A1) and (A2) jointly entail sub-conclusion (A3), i.e., if a perfectly loving God exists, then such a God always intrinsically desires any finite person to have their greatest attainable degree of union among God and all relevant parties a.s.a.p.

In the next sub-section, I explain one necessary condition of any finite person having their greatest attainable degree of union among God and all relevant parties a.s.a.p.

\section{Premise (A4)}

According to Stump, if my adult cognitive faculties are functioning properly, then I will always grasp (on some level) the objective value there is in the world, including what morality requires. However, if I do not wholeheartedly desire to comply with what morality requires, then (on Humean externalism) I will always be somewhat motivated to perform actions that I know to be wrong. ${ }^{4}$ In that case, I will be somewhat divided against myself, or psychically fragmented:

I do not understand what I do. For what I want to do I do not do, but what I hate I do. And if I do what I do not want to do, I agree that the law is good...

\footnotetext{
${ }^{4}$ King $(2014,215)$ : "Despite being a cognitivist...Aquinas is also an externalist."
} 
Now if I do what I do not want to do, it is no longer I who do it... (Romans $7: 15-17$, NIV)

Unfortunately, my psychic fragmentation, or lack of internal integration around the good, prevents me from having the greatest attainable degree of union with others and myself:

To the extent to which a person is divided against himself, to that extent, he cannot be at one with others either. The lack of internal integration is therefore inimical to the union desired in love...even God cannot be close to a person and united with a person who is not close to himself...[Yet] closeness can be more or less rich... and in consequence... union itself comes in degrees (Stump 2010, 127, 130, 390).

Therefore, anything that contributes to someone's internal integration in goodness also brings them closer to God and all relevant parties. However, it is important to note that God cannot unilaterally eliminate my psychic fragmentation because a union of love requires two wills that share mutual personal presence and mutual closeness. $^{5}$

Accordingly, if a perfectly loving God exists who always intrinsically desires any finite person to have their greatest attainable degree of union among God and all relevant parties a.s.a.p., then such a God always intrinsically desires any finite person to attain the state of wholeheartedly desiring to comply with what morality requires a.s.a.p.

Premises (A3) and (A4) jointly entail sub-conclusion (A5), i.e., if a perfectly loving God exists, then such a God always intrinsically desires any finite person to attain the state of wholeheartedly desiring to comply with what morality requires a.s.a.p.

Assuming everything above is true, there remains the problem of how any psychically fragmented person can attain the state of wholeheartedly desiring to comply with what morality requires a.s.a.p. In the next sub-section, I explain one necessary condition of Stump's solution to this problem.

\section{Premise (A6)}

According to Stump, any psychically fragmented person can attain the state of wholeheartedly desiring to comply with what morality requires only if they have a sustained global second-order volition/desire for a will that wills the good: ${ }^{6}$

\footnotetext{
${ }^{5}$ Later in the paper, I offer a response-by reasoning "from above" - to the objection that says, God would not have caused or allowed any finite person to be psychically fragmented in the first place.

6 If someone is currently incapable of forming a global second-order desire to be moral, for whatever reason, (e.g. environmental, genetic), then perhaps God: “...if he exists and is perfectly loving, will at some future point in that individual's life, or in the hereafter, provide him with the capacities required for this and other forms of well-being (Schellenberg 2003, 24-25)." Finally, my argument leaves it an open question as to whether finite persons require divine grace in some way (or not) to form an ongoing global second-order desire to be moral.
} 
Paula's second-order desire for a first-order desire not to eat meat...is predicated not only on her desires as regards her own contribution to the ethical treatment of animals but also on her general higher-order desire to be an ethical person...So...all the more localized higher-order desires of the person being sanctified are predicated on a global second-order will for a will that wills the good... as long as a human person has a second-order desire for a will that wills the good, she will eventually have what she wants: a will entirely integrated in goodness (Stump 2010, 162-164)."

I hasten to add that Aquinas-Stump assume there is an immortal afterlife for all psychically fragmented persons who continue to have the relevant global second-order desire-without ever permanently losing it. Otherwise, it would not follow that all relevant parties could eventually reach a state of being internally integrated in goodness; say, if they were forever annihilated from existence before they ever reached that state.

Indeed, given the possibility of moral backsliding and moral stagnation (at least in this life), it may only be in an immortal afterlife that all relevant parties can attain the state of wholeheartedly desiring to comply with what morality requires (Stump $2010,161)$. In that connection, it is important to note that "[i]t is possible...for a person to have a second-order desire for a will that wills the good and reject a particular reform that he sees as morally needed but that he finds himself unable to accept at a particular time (Stump 2010, 164)." Consequently, any finite person P is resistant (simpliciter) to union among God and all relevant parties, at any time $\mathrm{t}$, only if $\mathrm{P}$ does not have a global second-order desire for a will that wills the good (hereafter: global second-order desire to be moral).

Thus, any nonresistant finite person can attain the state of wholeheartedly desiring to comply with what morality requires a.s.a.p. only if their global second-order desire to be moral is optimally sustained. Therefore, if a perfectly loving God exists who always intrinsically desires any finite person to attain the state of wholeheartedly desiring to comply with what morality requires a.s.a.p., then such a God always intrinsically desires to optimally sustain any nonresistant finite person's global second-order desire to be moral.

Premises (A5) and (A6) jointly entail sub-conclusion (A7), i.e., if a perfectly loving God exists, then such a God always intrinsically desires to optimally sustain any nonresistant finite person's global second-order desire to be moral.

In the next section/sub-section, I argue that if Humean externalism is true, then it can vary throughout the lifetime of any nonresistant finite person whether theistic or non-theistic resources in their nature or their environment optimally sustain their global second-order desire to be moral.

\section{Humean externalism}

\section{Premise (A8)}

Consider the following four claims (one from metaethics, and three from moral psychology): 
(C1) Moral judgments are beliefs.

(C2) Moral judgments are essentially motivating.

(C3) Volitions/desires are the ultimate source(s) of motivation.

(C4) There is no necessary connection between any belief and any volition/ desire.

Claim (C1) encapsulates cognitivism, the view in metaethics that moral judgments sometimes embody knowledge; and therefore, are states of belief. Claim (C2) encapsulates motivational internalism, the view in moral psychology that if an agent forms the moral belief that they ought to do something, then he or she will be at least somewhat motivated to act in accordance with that belief. On this view, beliefs and desires do not have distinct natures. Claim (C3) encapsulates Humeanism, the view in moral psychology that beliefs neither motivate nor generate any motivationally efficacious states apart from an agent's volitions/desires. Claim (C4) encapsulates motivational externalism, the view in moral psychology that if any connection exists between some belief and some volition/desire, then that connection is contingent. On this view, beliefs and volitions/desires have distinct natures.

Here is the issue: many have found claims $(\mathrm{C} 1)-(\mathrm{C} 4)$ plausible, but assuming the truth of all four claims leads to inconsistency. ${ }^{7}$ One way to avoid inconsistency is to reject motivational internalism (C2) and accept cognitivism (C1), Humeanism (C3), and motivational externalism (C4). In fact, the truth of cognitivism (the dominant view in metaethics), ${ }^{8}$ and Humeanism (the dominant view in moral psychology), ${ }^{9}$ jointly entail motivational externalism. ${ }^{10}$

As such, let us discuss a standard alethic characterization of Humean externalism:

Explanatory Humean Externalism: Necessarily, whenever an agent engages in some action, $x$, the complete explanation of $x$ must cite one or more of her motivational states as the ultimate source(s) of $x$, and one or more of her informational states as the efficient and final cause(s) of $x$ (Swartzer 2015, 3-4).

Put simply; the complete explanation of an agent's action must be the product of two different kinds of mental states: motivational states, and informational states.

\footnotetext{
${ }^{7}$ For a demonstration of this inconsistency, see Brink $(1997,6)$.

${ }^{8}$ Bourget and Chalmers (2014, 95).

${ }^{9}$ Rosati (2016), https://plato.stanford.edu/archives/win2016/entries/moral-motivation/:

It would perhaps be fair to say that Humeanism continues to be the dominant view.

${ }^{10}$ We can show this by letting 'J' stand for moral judgment, 'B' for moral belief, 'M' for motivation, and 'D' for desire:

1. Necessarily, J iff B-claim (1).

2. Possibly, J \& not-M-not-claim (2)

3. Impossibly, if J, then $\mathrm{M}$.

4. Necessarily, if M then D-claim (3).

5. Impossibly, if J, then D.

6. Possibly, J \& not-D.

7. Possibly, B \& not-D. 
Volitions/desires constitute motivational states. Their strength can vary throughout an agent's lifetime, and they determine an agent's ends and 'drive' him or her toward attaining them. Beliefs and other cognitive states constitute informational states. Despite lacking motivational force, informational states are invariably action guiding because there are usually a determinate number of ways in which an agent may act in accord with, or contrary to, her motivational states (Svavarsdottir 1999, 162). Relatedly, the content of informational states can differentially engage and sustain an agent's motivational states by telling them how likely it is that various actions might promote their ends (Swartzer 2015, 3).

Accordingly, the complete explanation of an agent's moral behavior is ".... matter of contingent psychological fact, depending on both the content of people's moral views and their attitudes and desires (Brink 1989, 49)." Fortunately, many people can avail themselves of widely shared and centrally rooted resources in their nature or their environment to harness and extend their grasp of what morality requires, as well as their desire to comply with what morality requires:

How we internalize norms, our experience of socialization, the way in which we learn to reason, our experience as religious [or irreligious] practitioners - these are the ways in which we undergo character development and fine-tune the [moral] capacities with which nature endows us (Flescher and Worthen 2007, 246).

As such, while it may be a contingent fact that most people have some grasp of what morality requires, as well as some desire to comply with what morality requires, it can be a widespread and deep fact about them. In this way, the Humean externalist can make her view compossible with Aquinas-Stump's view that no sane person (in the actual world) is or has been wholeheartedly evil. ${ }^{11}$

Here is the crucial point: if Humean externalism is true, then it can vary throughout the lifetime of any nonresistant finite person whether theistic or non-theistic resources in their nature or their environment optimally sustain their global secondorder desire to be moral. ${ }^{12}$ To see that this is so, consider three additional points about the resources in most people's nature or environment that can function to

\footnotetext{
${ }^{11}$ Stump (2010), 139:
}

....Aquinas could accept the possibility of.... person who is single-minded and whole-hearted in evil—as long as he could judge such a person insane, in virtue of that person lacking the ability to discern by reason the objective value that is really there in the world. In such judgment, of course, Aquinas would not be dissenting from common opinion.

${ }^{12}$ If Humean externalism is true, then my main argument is compatible with Aquinas-Stump's theological beliefs about faith and justification:

...for Aquinas, there is implicit as well as explicit faith...some of those who lived before the advent of Christ or who live in places where Christianity is not known might nonetheless count among those saved by faith because of their right relation to God, the object of faith, even if they do not explicitly hold the articles of faith... (Stump 2010, 163).

Moreover, if Humean externalism is true, then my main argument is also compatible with AquinasStump's theological belief that grace is required for justification and sanctification. Why? Because the resources that operate individually or combine to cause or sustain any nonresistant finite person's global second-order desire to be moral can be indirect gifts of grace, or direct gifts of grace. 
harness and extend their grasp of what morality requires, as well as their desire to comply with what morality requires.

First, these resources comprise six categories (each containing various subcategories): psychological mechanisms, ${ }^{13}$ social mechanisms, ${ }^{14}$ moral reasoning, ${ }^{15}$ non-moral reasoning, ${ }^{16}$ religious concepts and practices, ${ }^{17}$ and irreligious concepts and practices. ${ }^{18}$ Second, these resources are determinate and widespread in that each instance of nonresistant nonbelief/belief in the actual world embodies some permutation of them. Third, on Humean externalism, permutations of these resources with different content might differentially sustain any nonresistant finite person's global second-order desire to be moral (throughout their lifetime):

...the disposition to be motivated by one's moral judgments is grounded in a conative attitude (desire) taken towards objects under a moral mode of presentation. For convenience, call it the desire to be moral. I expect that it varies from agent to agent which other mental states sustain that desire. In some cases, it may be sustained by a healthy dose of sympathy with others, as well as an acceptance of a norm of benevolence. In other cases, it will, instead or additionally [emphasis added], be sustained by a desire to be able to justify one's conduct from an impartial standpoint. But undoubtedly, there are also cases in which it is sustained, say, by an awe of God and a theological view of the foundations of morality, or by a fear of punishment. It may also just stand there pretty much on its own, not dependent on any other motive at that stage in the person's life. I doubt there is any unique psychology that sustains a disposition to be motivated by one's moral judgments... (Svavarsdottir 1999, 170-171).

Accordingly, Humean externalism does not entail that either theistic or non-theistic permutations of these resources, but not both, can sustain any nonresistant finite person's global second-order desire to be moral (throughout their lifetime). Instead, if Humean externalism is true, then it can vary throughout the lifetime of any nonresistant finite person whether permutations of theistic or non-theistic resources optimally sustain their global second-order desire to be moral.

Thus, a perfectly loving God might intrinsically/derivatively desire to promote/ permit permutations of theistic or non-theistic resources to optimally sustain every nonresistant finite person's global second-order desire to be moral (throughout their lifetime). Moreover, if that were the case, then we would predict that, on average, all the relevant theistic and non-theistic parties would exhibit parallel levels of moral development across time and space. As it happens, when we survey the world as it

\footnotetext{
13 E.g., sympathy, empathy.

14 E.g., group-level functional organization.

15 E.g., the informal ways in which we learn to reason morally (i.e., parents, culture, etc.) and the formal ways (i.e., normative systems of ethics).

16 E.g., logic.

17 E.g., concepts about the purpose of life, spiritual disciplines, etc.

18 E.g., Humanism, Existentialism, Reason Rallies, etc..
} 
is, and has been, all the available and relevant empirical evidence appears to confirm this prediction:

I see no [empirical] evidence [from history or scientific studies] at all that people who profess to believe that there is an orthodoxly conceived monotheistic god are more virtuous than those who fail to profess to believe that there is an orthodoxly conceived monotheistic god...Given the variation in the proportions of theists and non-theists, and the difficulties that face the 'summation' of goods and evils, I see no prospect of arriving at an uncontroversial answer to the question of whether, on the whole, those who have believed that there is an orthodoxly conceived monotheistic god have been morally better than those who have failed to hold this belief (Oppy 2006, 357).

In that connection, all instances of nonresistant nonbelief/belief might exist or have existed to optimally sustain every nonresistant finite person's global secondorder desire to be moral.

Therefore, (given the three points above) if a perfectly loving God always intrinsically desires to optimally sustain any nonresistant finite person's global secondorder desire to be moral, then such a God might derivatively desire to permit various types and tokens of nonresistant nonbelief for some time.

Premises (A7) and (A8) jointly entail sub-conclusion (A9), i.e., if a perfectly loving God exists, then such a God might derivatively desire to permit various types and tokens of nonresistant nonbelief for some time.

In the next sub-section, I explain why premise (A10) might be true.

\section{Premise (A10)}

Recall, on Humean externalism, that desires determine an agent's ends and 'drive' him or her toward attaining them. Accordingly, if a perfectly loving God derivatively desires to permit various types and tokens of nonresistant nonbelief (as a necessary means toward the intrinsically desired end of optimally sustaining the global second-order desire of all relevant parties), then such a God might be driven to be temporarily closed to union with all relevant parties.

Premises (A9) and (A10) jointly entail main conclusion (A11), i.e., if a perfectly loving God exists, then such a God might not be perpetually open to union with any finite person.

\section{Objections}

In the last two sections, I consider two objections to my main argument and then conclude the paper. 


\section{First objection}

If God created finite persons who start off wholeheartedly desiring to comply with what morality requires, then the greatest attainable degree of union would exist among God and all relevant parties a.s.a.p. Therefore, if a perfectly loving God exists who always intrinsically desires any finite person to have their greatest attainable degree of union among God and all relevant parties a.s.a.p., then such a God would not cause or allow any finite person to be psychically fragmented in the first place.

\section{Response}

According to Aquinas-Stump, if any finite person shares significant personal presence (in its fullest sense) among God and all relevant parties-and thus, significant closeness (in its fullest sense) with them as well-then that person has attained the greatest degree of union among God and all relevant parties. However, it is conceptually more plausible to believe that if any finite person has attained the greatest degree of union among God and all relevant parties, then they have attained fullest union (in the sense above) and deepest union with them.

Consequently, if a perfectly loving God exists who always intrinsically desires any finite person to have their greatest attainable flourishing a.s.a.p., then such a God always intrinsically desires any finite person to have their fullest and deepest attainable degree of union among God and all relevant parties a.s.a.p. In that connection, here is the crucial point: only psychically fragmented persons who eventually attain integration in goodness, in a certain way (defended below), can have the fullest and deepest attainable degree of union among God and all relevant parties.

To see why, first recall that if any finite person does not wholeheartedly desire to comply with what morality requires, then they cannot have fullest union among God and all relevant parties.

Moreover, any finite person can attain their deep(est) union among God and all relevant parties only if the deep(est) act(s) of love feature(s) as prominently as possible in their union. In support of this conceptual truth, consider a deep union of love from J.R.R. Tolkien's Lord of the Rings: The Fellowship of the Ring. In this book, the elf character named Arwen performs a deep act of love by voluntarily deciding to give up her elven immortality so that she can marry Aragorn, the human she loves. ${ }^{19}$ To understand why this is such a deep act of love, it is important to know that in the Tolkien universe, if an elf marries a human, then both persons will eventually die. On the other hand, if an elf marries another elf, then both persons can live forever.

Given this background information, we can understand how Arwen's act fulfills the two desires of love. That is, Arwen intrinsically desired union with Aragorn, where that union was also conducive to their true flourishing. However, she only

\footnotetext{
19 Recall that the hiddenness argument includes any possible finite persons in its universe of discourse, including elves.
} 
derivatively desired the (mortal) conditions that were necessary to have union with him-conditions to which she consented. Therefore, we can say that Arwen's act of voluntarily giving up her elven immortality to marry Aragorn is loving.

Here is the crucial point: the reason Arwen's act is a deep act of love, and the reason that act features so prominently in her marital union with Aragorn is the same; namely, she performed an act of deep(est) self-sacrifice that played at least a very prominent role in having marital union with her beloved. Notice that immortal elves who are betrothed cannot have a deep union of love, in this way, even if they can have fullest marital union with one another. Analogously, it is hard to see how any finite person who starts off internally integrated around the good can have deep(est) union among God and all relevant parties, even if they can have fullest union among God and all relevant parties.

To begin to see why, notice that if any finite person starts off internally integrated around the good, then (on Humean externalism) that entails they start off wholeheartedly desiring to comply with what morality requires. Moreover, if any finite person starts off wholeheartedly desiring to comply with what morality requires, then they would seem to start off with everything they need-internally-to obtain fullest union among God and all relevant parties. Furthermore, since a union of love requires two uncoerced wills, neither God, nor any other person, can obtain union with any finite person who starts off internally integrated around the good in virtue of external forces coercing them.

Accordingly, it is hard to see how God, or any other person, could perform some act(s) of deep(est) self-sacrifice external to any finite person who starts off internally integrated around the good, which might also play as prominent a role as is possible in them obtaining union among God and all relevant parties. Thus, it is hard to see how any finite person who starts off internally integrated around the good can obtain fullest and deep(est) union among God and all relevant parties.

On the other hand, psychically fragmented persons can have fullest and deep(est) union among God and all relevant parties, but only if (1) God or (2) all relevant parties perform the relevant acts of self-sacrifice.

1. Suppose God performs some act(s) of deep(est) self-sacrifice that plays at least a very prominent role in one or more psychically fragmented persons attaining and sustaining internal integration around the good. In this way, God's act(s) of deep(est) self-sacrifice would play at least a very prominent role in one or more psychically fragmented persons attaining and sustaining union among God and all relevant parties. In fact, it is hard to conceive of some other act(s) of deep(est) self-sacrifice God could perform, which would play a more prominent role in any finite person attaining and sustaining union among God and all relevant parties. Thus, it is hard to see how any finite person-who was not once psychically fragmented — could attain and sustain fullest and deep(est) union among God and all relevant parties.

Admittedly, however, I do not see how an omnipotent, omniscient, and omnibenevolent God could perform any self-sacrificial acts apart from the possibility of something akin to the Christian doctrine of the Incarnation. Why? Because anything an omni-God can do, she can do effortlessly, without deliberation, and with a 
perfectly clear conscience. ${ }^{20}$ Fortunately, while my main argument provides us with abstract reason to expect something akin to the Christian doctrine of the Incarnation, it does not depend on the logical coherence of such an Incarnation.

2. To see why, suppose that one or more psychically fragmented persons perform some act(s) of deep(est) self-sacrifice that play(s) at least a prominent role in themselves or other such fragmented persons attaining and sustaining internal integration around the good. ${ }^{21}$ In this way, some psychically fragmented person's act(s) of deep(est) self-sacrifice would play a very prominent role in one or more such persons attaining and sustaining union among God and all relevant parties. In fact, it is hard to conceive of some other act(s) of deep(est) self-sacrifice that any finite person could perform, which would play a more prominent role in any finite person attaining and sustaining union among God and all relevant parties. Thus, it is hard to see how any finite person - who was not once psychically fragmented — could attain and sustain fullest and deep(est) union among God and all relevant parties.

Therefore, whether or not a perfectly loving God can perform any acts of self-sacrifice, such a God might always intrinsically desire psychically fragmented persons to become permanently integrated in goodness (in the way above) a.s.a.p.-so that they can have their fullest and deepest attainable degree of union among God and all relevant parties a.s.a.p.

\section{Second objection}

Doesn't my main argument assume the seemingly contingent fact that a perfectly loving God would want to relate to finite persons who require a sustained global second-order desire to be moral? If so, then my main argument commits the familiarity fallacy after all because it is not entirely supported by abstract reasoning "from above."

\section{Response}

Recall, in response to the previous objection, I argued that: if a perfectly loving God exists who always intrinsically desires any finite person to have their fullest and deepest attainable degree of union among God and all relevant parties a.s.a.p., then such a God might always intrinsically desire psychically fragmented persons to become permanently integrated in goodness (in a certain way) a.s.a.p. In that connection, it is hard to see (on Humean externalism) how any psychically fragmented person can attain/sustain internal integration around the good without having something functionally equivalent to a sustained global second-order desire to be moral.

\footnotetext{
${ }^{20} \mathrm{I}$ am grateful to an anonymous referee for raising this objection.

21 Of course, I am making two (plausible) assumptions here. One being that psychically fragmented persons (e.g., embodied human beings) can perform some act(s) of deep(est) self-sacrifice that promote(s) the flourishing of all relevant parties. The other being that (at least) some psychically fragmented person(s) - myself included-would explicitly or implicitly consent to performing some act(s) of deep(est) self-sacrifice so long as it would be conducive to the greatest attainable flourishing for themselves or others.
} 
To begin to see why, recall that if any finite person attains/sustains fullest and deep(est) union among God and all relevant parties, then they probably must attain/ sustain internal integration around the good, in a certain way (already defended above). Also, if anyone attains/sustains internal integration around the good, in this way, then that entails they once were psychically fragmented. Therefore, if any finite person attains/sustains fullest and deepest union among God and all relevant parties, then they once were psychically fragmented.

Moreover, if any person once was psychically fragmented, then he or she once had at least some fragmented volitions/desires. Why? Because the concept of a person entails having volitions/desires (Stump 2010, 93, 386-387, and 543). As such, if any person attains/sustains fullest and deep(est) union among God and all relevant parties, then that entails they once had at least some psychically fragmented volitions/desires.

Furthermore, if any person who was once psychically fragmented attains/sustains internal integration around the good, then (on Humean externalism) anyone being so integrated will be a matter of certain internal relations attaining/sustaining among all their particular volitions/desires.

Here is the crucial point: it is hard to see (on Humean externalism) how all of one's fragmented volitions/desires can be 'driven' to attain/sustain internal integration around the good apart from a general, or global volition/desire for all of one's particular volitions/desires to comply with what morality requires. Therefore, since a global volition/desire for all of one's particular volitions/desires to comply with what morality requires just is a global higher-order volition/desire to be moral, it is hard to see (on Humean externalism) how any psychically fragmented person could attain/sustain internal integration around the good without a sustained global higherorder desire to be moral.

Consequently, it is not a contingent fact that a perfectly loving God always desires to relate to finite persons who require a sustained global second-order desire to be moral.

\section{Conclusion}

My goal here was to respond to Schellenberg's hiddenness argument by drawing out a hitherto unnoticed intersection between the philosophy of love, metaethics, moral psychology, and the philosophy of religion. In particular, I hope I have shown that a perfectly loving God might not be perpetually open to a union with any (i.e., every) finite person if Aquinas-Stump's account of the nature of love is true, and if Humean externalism is true. If my main argument is sound, then Schellenberg's hiddenness argument might not show that atheism is true.

In closing, please recall the six categories of resources in most people's nature or environment that can function to harness and extend their grasp of what morality requires, as well as their desire to comply with what morality requires. Since permutations of these resources predictably constrain, but do not predetermine the content of the other mental states that might optimally sustain every nonresistant finite 
person's global second-order desire to be moral, the fundamental logic of my main argument can be harnessed and extended to help explain why (on theism):

(T1) the subjects of theistic experiences pursue a variety of radically different religious paths, none of which bears abundantly more moral fruit than all the others (Draper 2002), ${ }^{22}$

(T2) the world is religiously ambiguous, with no compelling proofs for or against any one religious or nonreligious interpretation of the world (Hick 1989), ${ }^{23}$

(T3) there is no sensus divinitatis (Maitzen 2006), ${ }^{24}$

(T4) there is a diversity of views among humans about any purpose or role they may or may not have been created to fulfill (Trisel 2012), ${ }^{25}$ and

(T5) there are a diversity of views among humans about many moral issues due to widespread disagreement in the domain of normative ethics (Swinburne $2007,85) .^{26}$

Open Access This article is distributed under the terms of the Creative Commons Attribution 4.0 International License (http://creativecommons.org/licenses/by/4.0/), which permits unrestricted use, distribution, and reproduction in any medium, provided you give appropriate credit to the original author(s) and the source, provide a link to the Creative Commons license, and indicate if changes were made.

\section{References}

Bourget, D., \& Chalmers, D. J. (2014). What do philosophers believe? Philosophical Studies, 170(3), 465-500.

Brink, D. O. (1989). Moral realism and the foundations of ethics. Cambridge: Cambridge University Press.

Brink, D. O. (1997). Moral motivation. Ethics, 107(1), 4-32.

Draper, P. (2002). Seeking but not believing: Confessions of a practicing agnostic. In D. Howard-Snyder \& P. K. Moser (Eds.), Divine hiddenness: New essays (pp. 197-214). Cambridge: Cambridge University Press.

Flescher, A. M., \& Worthen, D. (2007). The altruistic species: Scientific, philosophical, and religious perspectives of human benevolence. Philadelphia: Templeton Foundation Press.

\footnotetext{
${ }^{22}$ It can vary for any nonresistant finite person which other types and tokens of theistic mental states (if any) might optimally sustain their global second-order desire to be moral throughout their earthly career.

${ }^{23}$ The existence of compelling non-basic justification for some large-scale theory of reality might actually preclude the requisite diversity of mental states needed to optimally sustain any nonresistant finite person's global second-order desire to be moral throughout their earthly career.

${ }^{24}$ The existence of a sensus divinitatis might actually preclude the requisite diversity of mental states needed to optimally sustain any nonresistant finite person's global second-order desire to be moral throughout their earthly career.

${ }^{25}$ It can vary for any nonresistant finite person which other types and tokens of mental states about the purpose of life might optimally sustain their global second-order desire to be moral throughout their earthly career.

${ }^{26}$ It can vary for any nonresistant finite person which other types and tokens of mental states about issues in normative ethics might optimally sustain their global second-order desire to be moral throughout their earthly career.
} 
Hick, J. (1989). An interpretation of religion: human responses to the transcendent. New Haven: Yale University Press. http://plato.stanford.edu/archives/sum2016/entries/divine-hiddenness/. Accessed 26 May 2018.

King, P. (2014). Emotions. In B. Davies \& E. Stump (Eds.), The Oxford handbook of Aquinas (Oxford handbooks). Oxford: Oxford University Press. (Reprint edition).

Maitzen, S. (2006). Divine hiddenness and the demographics of theism. Religious Studies, 42(2), $177-191$.

Oppy, G. (2006). Arguing about Gods. Cambridge: Cambridge University Press.

Rosati, C. S. (2016). Moral Motivation. In E. N. Zalta (Ed.), The Stanford encyclopedia of philosophy. https://plato.stanford.edu/archives/win2016/entries/moral-motivation/. Accessed 4 Jan 2018.

Schellenberg, J. L. (1993). Divine hiddenness and human reason. Ithaca: Cornell University Press.

Schellenberg, J. L. (2007). The wisdom to doubt: A justification of religious skepticism. Ithaca: Cornell University Press.

Schellenberg, J. L. (2008). God or blind nature? Philosophers debate the evidence: What divine hiddenness reveals, or How weak theistic evidence is strong atheistic proof. Internet Infidels (Online Publisher). http://infidels.org/library/modern/john_schellenberg/hidden.html. Accessed 14 Sept 2017.

Schellenberg, J. L. (2010). The hiddenness problem and the problem of evil. Faith and Philosophy, 27(1), 45-60.

Schellenberg, J. L. (2015). The Hiddenness Argument: Philosophy's New Challenge to Belief in God (1st ed.). Oxford: Oxford University Press.

Schellenberg, J. L. (2016). Divine hiddenness and human philosophy. In A. Green \& E. Stump (Eds.), Hidden divinity and religious belief. Cambridge: Cambridge University Press.

Schellenberg, J. L. (2017). Divine hiddenness: part 1 (recent work on the hiddenness argument). Philosophy Compass, 12(4), 1-9.

Stump, E. (2010). Wandering in darkness: Narrative and the problem of suffering. Oxford: Clarendon Press.

Svavarsdottir, S. (1999). Moral cognitivism and motivation. Philosophical Review, 108(2), 161-219.

Swartzer, S. (2015). Humean externalism and the argument from depression. Journal of Ethics \& Social Philosophy, 9(2), 1-16.

Swinburne, R. (2007). Revelation: from metaphor to analogy. Oxford: Oxford University Press.

Trisel, B. A. (2012). God's silence as an epistemological concern. Philosophical Forum, 43(4), 383-393. 